\title{
The Enforcement of Counter-Radicalism through Educational Values (Analytical analysis of the Book of I'tiqād by Al-Bukhārī)
}

\author{
Hanif Muhammad Kamil1* ${ }^{*}$, Hudzaifah Achmad Qotadah², Iqbal Syafri ${ }^{3}$ \\ ${ }^{1,3}$ Sunan Kalijaga State Islamic University Yogyakarta, Indonesia \\ ${ }^{2}$ Acedemy of Islamic Studies, University of Malaya, Malaysia \\ *Corresponding Author Email: Hanifkamil86@gmail.com
}

\begin{abstract}
Radicalism is an understanding of social life, far beyond reconciliation and communication, similar to acts of violence. This misconception is indeed very dangerous, particularly if it is made in the name of religion itself. Evidently, the religious principle which always encourages a good and ethical way of life seems to have been misunderstood, perhaps abused. Radicalism might be handled and prevented by implementing the teachings of Imam al-Bukhārī, e.g. the I'tiqād, a clear understanding of religion and outstanding teaching practices. The aim of this research is to analyze the contents of the book upon its values of Islamic teachings concerning harmony through living together under a foundation of educational values towards radicalism. The research employed a full qualitative method and data documentation related to the research, which was then analyzed descriptively. In the meantime, the results of the study revealed that Imam al-Bukhārī, in his book I'tiqād al-Bukhārī, proposed four (4) educational values or elements of peace in Islamic teachings, namely: (1) harmony with the public at large, (2) harmony with the government, (3) tranquility with the Muslims, and (4) harmony with believers of other religions. These educational values could be an instructional approach for the enforcement of counter-radicalism that would be applicable to Islamic education in Indonesia.
\end{abstract}

Keywords: Enforcement, Counter Radicalis, Education, I'tiqād Al-Bukhārī.

\begin{abstract}
ABSTRAK
Radikalisme merupakan paham dalam kehidupan sosial yang jauh dari cara-cara kompromi dan komunikasi, sehingga dekat dengan tindakan kekerasan. Paham ini sangat berbahaya, apalagi jika dilakukan dengan mengatasnamakan agama, karena agama yang mengajarkan jalan hidup yang baik dan benar telah disalahpahami, bahkan disalahgunakan. Paham radikalisme dapat dikendalikan dan ditanggulangi dengan menanamkan pemahaman agama yang benar serta nilai-nilai pendidikan yang baik sebagaimaa yang terdapat dalam kita karya Imam al-Bukhārī yaitu kitab I'tiqād. Adapun objektif penelitian ini ialah untuk mengkaji isi kitab tersebut berkaitan dengan prinsip ajaran Islam tentang kedamaian dalam hidup bersama, sebagai sumber nilai pendidikan kontra-radikalisme. Metode yang digunakan penulis dalam penelitian ini ialah dengan menggunakan metode kualitatif penuh serta data dokumentasi yang terkait dengan topik kajian penelitian ini, kemudian dianalisis secara deskriptif. Alhasil, Imam al-Bukhārī dalam kitabnya I'tiqād al-Bukhārī, merumuskan 4 (empat) nilai pendidikan atau pilar kedamaian dalam ajaran Islam yaitu; (1) damai dengan masyarakat umum, (2) damai dengan pemerintah, (3) damai dengan sesama umat Islam, dan (4) damai dengan penganut agama lain. Nilai-nilai pendidikan tersebut dapat menjadi sebuah strategi pendidikan dalam menegakkan kontra-radikalisme yang relevan dengan pendidikan Islam di Indonesia.
\end{abstract}

Kata kunci: Penegakan, Kontra Radikalisme, Pendidikan, I'tiqād Al-Bukhārī.

\footnotetext{
* Copyright (c) 2020 Hanif Muhammad Kamil, Hudzaifah Achmad Qotadah, Iqbal Syafri

This work is licensed under a Creative Commons Attribution-ShareAlike 4.0

International License.
}

Received: October 24, 2020; Revised: November 3, 2020; Accepted: November 4, 2020 
Khazanah Sosial, Vol. 2 No. 3: 179-189

The Enforcement of Counter-Radicalism through Educational Values (Analytical analysis of the Book of I'tiqād by Al-Bukhārī)

Hanif Muhammad Kamil, Hudzaifah Achmad Qotadah, Iqbal Syafri

\section{INTRODUCTION}

Nowadays, radicalism and terrorism have become national and international issues and received enormous attention. This issue has not gone unnoticed by the government by preventing radicalism and combat acts of terrorism. The emergence of radicalism and acts of terror in people's lives cannot be separated from ideological, historical, social, economic, and political aspects. This phenomenon is part of the dynamics of regional, even global life. Although Indonesians mostly did the recent acts of radicalism and terror in various regions, it cannot be denied that these acts are a combination of domestic actors (indigenous) and transnational networks (trans-national networks) (Hikam, 2016).

Radicalism can happen to anyone, anytime, and anywhere, including children, adolescents, and adults. It does not matter whether they are rich or poor, and it does not matter whether they come from the elite or ordinary community. Radicalism does not appear instantly. It arises due to various experiences of each individual or community group. A narrow way of thinking and understanding can be a driving force for the birth of radicalism, either in the aspects of social, political, economic, education, and even religion. Radicalism can be prevented and eliminated through guidance and supervision against the way of thinking and perspective of a phenomenon's changes due to the times' development. On the other hand, radicalism can be controlled by creating a sense of security and a fair environment in all aspects of everyday life (Muchith, 2016).

Changes and developments in science, technology, culture, social, political, economic, and other aspects that occurred with the reformation certainly need to be guided and directed to impact society positively. They need the right orientation through education and good habituation in people's lives, and they also need an excellent example from the leaders. Good community requires the development of fairness to establish harmony within the community, mutual respect within the members, and the willingness to help each other. Furthermore, creating those situations will change selfishness, an act of underestimating, and a priori, which results in a lack of compliance with one another, into a tolerant attitude, mutual help, and mutual respect (Alia et al., 2020; Hidayat, 2020; Muchith, 2016).

Islam consistently teaches peace. The principle of peace is not limited only to normative teaching but also to implementing the value in Muslims' lives from the very beginning, as exemplified by the Prophet Muhammad. Friends of the Prophet Muhammad and pious people continued to implement this value of living in peace. The Ulama's commitment to living in harmony with a strong brotherhood, tolerance, and avoiding various forms of violence is part of Islam's life principles. The formulations of the Islamic tenets can be found in a book that was written by Imam Al-Bukhārī, who specifically wrote a book entitled I'tiqād al-Bukhārī. This book contains the Islamic creed's main points that teach a peaceful attitude and prohibits destructive radicalism. The writings of Imam al-Bukhārī contain the main educational values aimed at Muslims to hold fast to their true religion.

In the context of Islamic education, this book is essential to study to elaborate on the values of counter-radicalism education and be the source of the correct understanding of Islamic creed. On the other hand, a study of counter-radical values written by a great ulama confirms that Islam is a religion that loves peace, has a high tolerance, a strong brotherhood, and unity. This paper is also one of the proofs and arguments that can straighten the negative stigma against Islam and its people. More than that, this study's results are expected to contribute to solving the problem of radicalism substantively and persuasively through correct education.

The previous study on counter-radicalism has been researched by Rohmatika (2016) about the Effectiveness of the Role of Islamic Education Teachers at SMP Negeri 9 Yogyakarta in Preventive Efforts to Counter the Propaganda of Islamic Radicalism in Students. This research discussion focused on Islamic 
Khazanah Sosial, Vol. 2 No. 3: 179-189

The Enforcement of Counter-Radicalism through Educational Values (Analytical analysis of the Book of I'tiqād by Al-Bukhārī)

Hanif Muhammad Kamil, Hudzaifah Achmad Qotadah, Iqbal Syafri

education teachers' role in making preventive efforts to avoid radicalism. Another research was conducted by Rahmawati (2014) on Deradicalization of Religious Understanding in Yusuf Qardhawi's Thought in terms of Islamic Religious Education Perspective. This research focuses on Yusuf Qardhawi's thoughts on radicalism and deradicalization efforts. Research reviewed by Rosanita (2016) regarding the Perceptions of Islamic Religious Education Teachers on Religious Radicalism: Multisite Studies in SMA Negeri 1, SMK Negeri 1, and MA Negeri 1 Kota Mojokerto. This study discusses perceptions, influencing factors, and preventive efforts of Islamic Education teachers at SMAN 1, SMKN 1, and MAN 1 Kota Mojokerto regarding religious radicalism.

As a result, the research studied by Maulidah Rohmatika and Umu Arifah Rahmawati is very different from the author's research. Maulidah Rohmatika's research emphasizes teachers' role to prevent understanding of radicalism in their students, while Umu Arifah Rahmawati's research emphasizes more on the discussion of Yusuf Qardhawi's thoughts. The research performed by Devi Rosanita has similarities with this study. The difference with this study lies in the object of the study.

Thus, based on the explanation above, the author will examine "The Enforcement of CounterRadicalism through Educational Values (Analysis of the I'tiqād Book by Al-Bukhārī). This study aims to determine the values of counter-radicalism in the I'tiqād Book by al-Bukhārī and its relevance to Islamic education in Indonesia.

\section{RESEARCH METHOD}

The study of I'tiqād al-Bukhārī book by Imam al-Bukhārī is a library research. In this study, a series of activities were carried out concerning library data collection, reading, taking notes, and processing research materials (Zed, 2004). The data source was books, magazines, journals, newsletters, newspapers, papers, and other media related to this research. The approach used in this research is the bibliographic. This approach uses historical methods to search, analyze, interpret, and generalize facts that are the opinions of experts in a problem (Nazir, 2014).

This research focuses on the results of thoughts and ideas written by Imam al-Bukhārī, in his book of I'tiqād al-Bukhārī as the primary source. Apart from these primary sources, this study also uses secondary sources; they are various relevant references [Saraswati] related to the research problem. Data analysis in this study uses analytic descriptive. It was carried out by describing and analyzing (Ratna, 2019). The type of data analysis used in this study is content analysis. It is a technique that allows researchers to study human behavior indirectly through the analysis of their communication [Fraenkel, 2012], and then it will be concluded with inductive reasoning.

\section{RESULTS AND DISCUSSION}

The root word of radicalism is radical. According to its meaning in language, radical is neutral. It can be related to positive and negative things. In KBBI, the term radical is associated with several definitions, starting from the primary meaning to something principle, intensely demanding changes in laws, governance, and means progress in thinking or acting. The radical meaning is linguistically neutral, not directly referring to a particular value or a positive or negative view. The term is different from terror, which means to scare other parties. Terror is always carried out in negative ways and frightens other parties (Muchith, 2016). In practice, radicalism becomes an understanding or flow that requires social and political change or renewal through violence (Ratna, 2019). Radicalism is also considered as an 
Khazanah Sosial, Vol. 2 No. 3: 179-189

The Enforcement of Counter-Radicalism through Educational Values (Analytical analysis of the Book of I'tiqād by Al-Bukhārī)

Hanif Muhammad Kamil, Hudzaifah Achmad Qotadah, Iqbal Syafri

understanding or way of thinking that becomes the basis for committing acts of violence or terror (Muchith, 2016).

The phenomenon of radicalism and violence occurring in society is a complex reality. Many factors have caused or triggered the emergence of radicalism, such as unfavourable socio-economic conditions, unfairness, globalization, modern imperialism, and narrow religious understanding. The accumulation of these various factors fosters radical attitudes and understandings, which can encourage someone to choose the path to join acts and networks of terrorism (BNPT, 2016). Today, the phenomenon of radicalism has become a challenge for many countries, including Indonesia.

Radicalism might happen in every aspect of life. It is encouraged by various reasons, either due to a wrong or narrow understanding of religious teachings, social injustice, poverty, politics, social inequality, etc (Kusmanto et al., 2015). Therefore, radicalism is a serious challenge and threat, so it is necessary to counter it. The effort of countering radicalism is called persuasive deradicalization (D. Syamsuddin, 2016). One of the efforts that can be applied is by enforcing a counter-radicalism through educational values as taught by the ulamas through their works such as the book I'tiqād al-Bukhārī by Imam al-Bukhārī.

\section{Short biography of Imam Al-Bukhärī}

Imam al-Bukhārī full name was Abū' Abdillāh Muhammad bin Ismā'īl bin Ibrāhīm bin al-Mugīrah bin Bardizbah al-Ju'fi. He was born on a Friday after the Friday prayer 13 Shawwal 194 H in Bukhara (Bucharest). When he was little, his father, Isma'il, had died, so her mother was the one raising him (Wahyudi, 2009). When he was still a child, his father died, and that made him a yatim and raised under his mother's care . Muḥammad bin Aḥmad bin Faḍl al-Balkhi said; I heard my father say, "Muhammad bin Ismā'îl sight has been taken away from him (blind) since childhood". One time his mother had a dream that she saw Ibrāhìm as said this to her, "O woman, Allah has returned your son's sight because of your frequent prayers. When morning came, it was true that Allah had returned the vision of Muhammad bin Ismā'il (Adz-Dzahabi, 2008).

Since he was a teenager, he rahimahulläh began to travel to trace the hadith in $210 \mathrm{AH}$. He moved from place to place in his country, searching for hadiths, and then lived in the Hejaz for six years. After that, he went to Syria, Egypt,Jazirah, Basra, Kufa, and Baghdad. Imam al-Bukhärī was known to have very strong memorization. People said that he could memorize a book with one reading. He was a very zuhud and wara 'person, far from the life of rulers and leaders. He was courageous and generous. His ability to memorize given by Allah SWT, was a tremendous asset to make him an expert in hadith science. He was able to memorize hadiths and understand them in detail (Al-Utsaimin, 2008).

Imam al-Bukhārī came to study with the Shaykhs in Basrah, but never wrote the hadiths, so they asked him, "Why don't you write?" then he recited all the hadiths he had heard by memorization, and the total of the hadith was up to more than fifteen thousand (Jauzi, 2006). The ulamas during his period and after his period praised him greatly. Imam Ahmad said, "Khurasan never took out someone as great as him." Ibn Khuzaimah said, "Under this sky, there is no one who knows better and memorizes the hadith of Rasūlullāh saw more than Muhammad bin Ismā'îl al-Bukhārī" (Al-Utsaimin, 2008). He is a mujtahid in the field of fiqh. He is meticulous in drawing legal conclusions on a hadith as can be seen in the chapter titles in his șahịh book (Al-Utsaimin, 2008).

He rahimahullāh died in Khartank, two farsakhs away from Samarkand on the night of Eid alfițri in $256 \mathrm{AH}$ at 62 . He left much knowledge in his various books. May Allah bestow His Mercy on him and give him a better reward for his services to the Muslims (Al-Utsaimin, 2008). Among the books by Imam 
Khazanah Sosial, Vol. 2 No. 3: 179-189

The Enforcement of Counter-Radicalism through Educational Values (Analytical analysis of the Book of I'tiqād by Al-Bukhārī)

Hanif Muhammad Kamil, Hudzaifah Achmad Qotadah, Iqbal Syafri

al-Bukhārī is the book I'tiqād (Az-Zahrani, 2011) in which this book explains the principles of Islamic teachings that contain counter-radicalism educational values.

\section{Overview of the Book I'tiqād Al-Bukhārī}

The complete title of the book is I'tiqād Abī 'Abdillāh Muhammad bin Ismā'il al-Bukhārī fỉ Jamā'ah min as-Salafallażīna Rawā' anhum which was passed on by Muhammad Ziyad bin 'Umar at-Tuklah in 1433 H (Al-Bukhārī, 2012b). This book is the result Imam al-Bukhārī 's thought in 'aqīiah, which was later narrated by Imam al-Lālikāî̀ (died $418 \mathrm{H}$ ) in the book of Syaraḥ Ușūl I'tiqād Ahlussunnah wal Jamā'ah. This book contains the results of the agreement of 1080 teachers of Imam al-Bukhārī who were ahlul hadith. The narrator of this book mentions some of Imam al-Bukhārī's teachers from various countries, namely the Hejaz, Mecca, Medina, Kufa, Basra, Wasith, Baghdad, Sham, and Egypt for 46 years (Al-Lālikā'î, 1995).

According to Imam al-Bukhārī, there are ten foundations in 'aqīdah, which the scholars have agreed. The following is a brief description of the ten points in the book I'tiqād al-Bukhārī, namely: First, it contains beliefs that a person can correctly call as Islam; Second, contains about belief in the Al-Qur'an; Third, contains about belief in destiny; Fourth, contains about infidelity; Fifth, contains about the attitude towards the companions of the Prophet Sallallāhu 'alaihi wa Sallam; Sixth, contains about bid'ah deeds; Fourth, contains about following the Sunnah of the Prophet Șallallähu 'alaihi wa Sallam; Eighth, contains attitudes towards the authorities; Ninth, contains attitudes towards Muslims; and Tenth, contains about praying to the leader.

\section{Educational Values of Counter-Radicalism Based on Book of I'tiqād Al-Bukhārī}

Deradicalization can be done persuasively through education and giving a correct understanding of various things, including religion. Education is all life situations that affect individual growth that lasts a lifetime. Therefore life is education, and education is life (Budiyanto, 2013). Education takes place in the context of multi-dimensional individual relationships, both in individual relationships with God, fellow humans, nature and even with themselves (Sajidiman, 2012). Education is also a social activity that allows society to exist and develop (Bahroni, 2009) not only on the quality of thinking but also on morals and kinesthetic intelligence (Muchith, 2016).

In connection with deradicalization efforts in the social dimension, it seems that it can only be reduced and countered by other social symptoms, which are the anti-radicalism movement. The response of the religious leaders is an expression of counter radicalism. The government and the public's attention to radicalism reflect that radicalism is a serious problem and is attached to it against radicalism (Kusmanto et al., 2015).

Counter-radicalization is one of the BNPT strategies to prevent radicalism and terrorism either through various activities such as socialization, dialogue, workshops, intelligence activities, etc, or by empowering civil society forces such as religious organizations, non-governmental organizations (nongovernmental organizations), educational institutions, religious leaders, traditional leaders, mass media, and former terrorists and so on as an effort to counteract radicalism in society (Tahir, 2016).

The ulamas have taught the basic principles of religion correctly as taught by the ulamas from the previous eras, the friends of the prophet and the Prophet Muhammad SAW, including through one of the works of Imam al-Bukhārī, namely the book I'tiqād al-Bukhārī. This book contains various aspects of the creed that are very basic to Muslims, including counter-radicalism educational values. The result shows four main pillars of the value of counter-radicalism education in the I'tiqād al-Bukhārī. The four pillars rest 
Khazanah Sosial, Vol. 2 No. 3: 179-189

The Enforcement of Counter-Radicalism through Educational Values (Analytical analysis of the Book of I'tiqād by Al-Bukhārī)

Hanif Muhammad Kamil, Hudzaifah Achmad Qotadah, Iqbal Syafri

on the main basic foundation, namely "peace," and its relevance can be drawn to Islamic education in Indonesia.

\section{The educational values of counter-radicalism contained in the book I'tiqūd Al-Bukhārī include}

\section{Being peaceful with the public}

I'tiqād al-Bukhārī stated that Islam had regulated its people always to practice the Sunnah whenever and wherever. Doing good deeds to neighbors, whether they are Muslims or not, is one of the forms of practicing the Sunnah from Rasūlullāh. Allah has arranged for His servants not to hurt their neighbors' hearts or physics, as Allah SWT said:

"Worship Allah alone and associate none with Him. And be kind to parents, relatives, orphans, the poor, near and distant neighbours, close friends, needy travellers, and those bondspeople in your possession. Surely Allah does not like whoever is arrogant, boastful." (QS an-Nisā: 36)

To be a good Muslim for the community, neighbors, and guests, a Muslim should not say something that will hurt others and behave well to make others feel comfortable. Rasūlullāh Șallallāhu 'alaihi wa Sallam said:

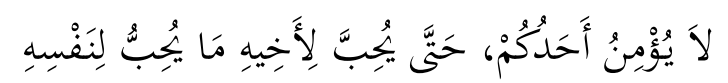

Meaning: "No one of you becomes a true believer until he likes for his brother what he likes for himself." (As-Suyuti, 1996).

From the explanation above, it can be seen that holding on to the Sunnah of Rasūlullāh Șallallāhu 'alaihi wa Sallam, such as being kind to neighbors and guests, contains the value of peace with the public. By following the Sunnah, a peaceful, loving society will be created and conflict in muamalah will be prevented.

\section{Being peaceful with the government}

In I'tiqād al-Bukhārī, Imam al-Bukhārī emphasizes the word of Allah as follow:

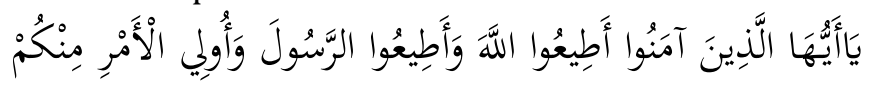

Meaning: "O believers! Obey Allah and obey the Messenger and those in authority among you.." (QS an-Nisā: 59).

Rebellion against the legitimate government can cause many harms; therefore, the ulama forbid the rebellion against the government. Rasūlullāh Șallallāhu 'alaihi wa Sallam said:

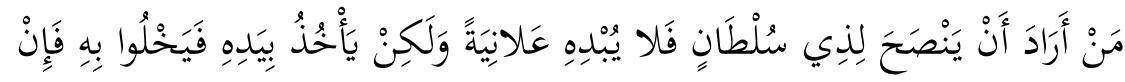

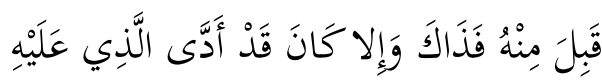

Meaning: "Whoever intends to advise one with authority, then he should not do so publicly. Rather, he should take him by the hand and advise him in seclusion. If he accepts the advice, then all is well. If he does not accept it, then he has fulfilled his duty" . (Albani, 1980)." 
Khazanah Sosial, Vol. 2 No. 3: 179-189

The Enforcement of Counter-Radicalism through Educational Values (Analytical analysis of the Book of I'tiqād by Al-Bukhārī)

Hanif Muhammad Kamil, Hudzaifah Achmad Qotadah, Iqbal Syafri

In Islamic teachings, people who can advise the leader are the people who have high knowledge and understand the country's political problem; they are the ulama that has reached the level of ijtihād and are experts in manifesting. The union of ulama and 'umarā' (leaders) will create a peaceful country. In addition, in the term of dealing with a foul leader, Rasūlullāh Șallallāhu 'alaihi wa Sallam has advised to be patient.

Rasūlullāh Șallallāhu 'alaihi wa Sallam telah memberikan nasehat untuk bersabar sebagaimana sabdanya:

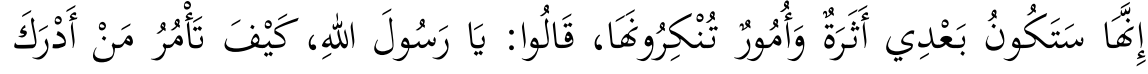

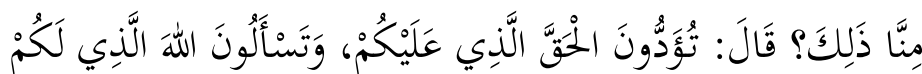

Meaning: "After me there will be favouritism anad many things that you will not like. They (his Companions) said: Messenger of Allah, what do you order that one should do it anyone from us has to live through such a time? He said: You should discharge your own responsibility (by obeying your Amir), and ask God to cuncede your right (by guiding the Amir to the right path or by replacing him by one more just and God-fearing)". [Al-Mubarakfuri, 1999]."

Rasūlullāh Șallallāhu 'alaihi wa Sallam said:

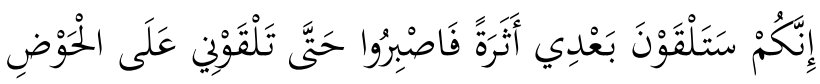

Meaning: "After me you will see others given preference to you, but you should remain patient till you meet me at the Haud (Al- Kauthar in Jannah) (Al-Asqalani, 2001)."

Rasūlullāh Sallallāhu 'alaihi wa Sallam also said:

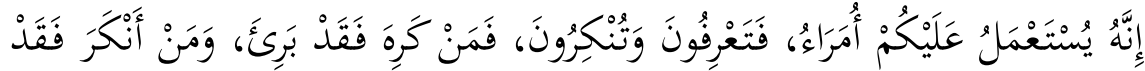

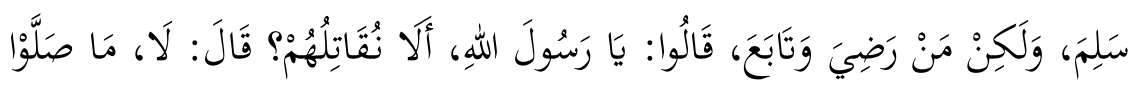

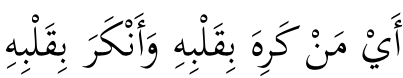

Meaning: "Amirs will be appointed over you, and you will find them doing good as well as bad deeds. One who hates their bad deeds is absolved from blame. One who disapproves of their bad deeds is (also) safe (so far as Divine wrath is concerned). But one who approves of their bad deeds and imitates them (is doomed). People asked: Messenger of Allah, shouldn't we fight against them? He replied: No, as long as they say their prayer. (" Hating and disapproving" refers to liking and disliking from the heart.) (Al-Naysabūrī, 2003)."

So, it can be concluded that when witnessing the evilness of leaders, the right action to act is to deny it with heart. Rebellion against a leader is only allowed when the Muslims see the real heathenism of the leader. It can only be done when the Muslims have equal or more power than the leader and will not cause greater harm because Islam is a peaceful religion, just like the Prophet's companions' understanding.

\section{Being peaceful with fellow Muslims}

Imam al-Bukhārī in his book I'tiqād al-Bukhārī emphasized one of Allah SWT's words in Surah anNisā'ayat 48: 
Khazanah Sosial, Vol. 2 No. 3: 179-189

The Enforcement of Counter-Radicalism through Educational Values (Analytical analysis of the Book of I'tiqād by Al-Bukhārī)

Hanif Muhammad Kamil, Hudzaifah Achmad Qotadah, Iqbal Syafri

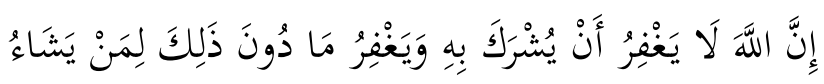

Meaning: "Indeed, Allah does not forgive associating others with Him in worship, but forgives anything else of whoever He wills." (QS an-Nisā': 48)"

Through his words, Imam al-Bukhärī emphasized the dangers of quickly claiming someone as an infidel. The labeling of infidel to fellow Muslims will result in great dangers, such as the act of murdering someone because an infidel's blood is halal to be killed. Thus, it is an obligation for all Muslims not to label someone as an infidel easily because a Muslim is obliged to be protected by his blood, property, and honor quickly.

Shaykh Muammad Nāṣiruddin al-Albānī Raḥimahullāh said, "Every immoral perpetrator, especially them who are spreading the current form of criminals, such as adultery, drinking khamar and others, are included as kufr amali. They should not be condemned as immoral because they commit immorality and justify actions, except after their heart intentions appear. And they believe that they do not believe in what is forbidden by Allah Ta'ālā and His Messenger, when we find out that they have fallen into an offense in their heart, they can be punished by infidels who leave Islam (Z. A. Syamsuddin \& Abidin, 2015).

There is also a rule to convert individually. That, too, must be returned to the judge in the sharia court. As said by Ibn Taimiyyah Raḥimahullāh:

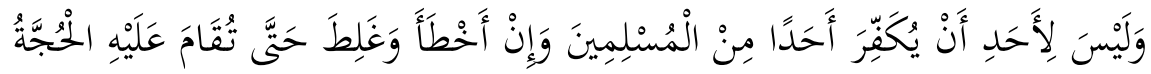

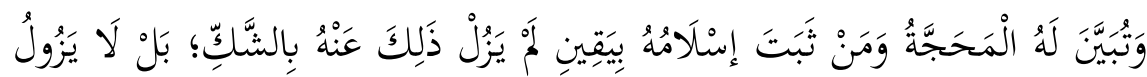

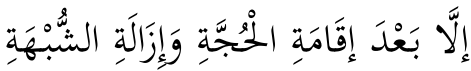

Meaning: "And it is not permissible for a person to disbelieve any of the Muslims even though he has made mistakes and mistakes until he has established blasphemy against him and it is clear to him that blasphemy. Furthermore, whoever believes then it is confirmed that it is not that Islam is lost from him only with doubt, but it can be lost except after upholding blasphemy and eliminating syubhat (Al-Harrani, 2004)."

Rasūlullāh Ṣallallāhu 'alaihi wa Sallam also said:

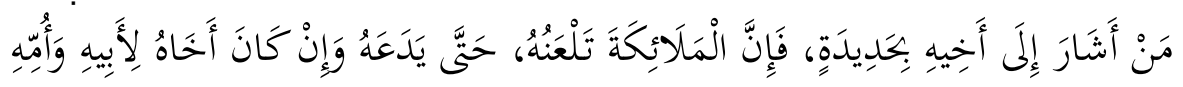

Meaning: "He who points at his (Muslim) brother with a weapon is cursed by the angels even if the other person should be his real brother (An-Nawawi, 1930)."

Based on the explanation above, it can be concluded that the book I'tiqād al-Bukhārī contains the value of peace with fellow Muslims. Islam obliges its people to make peace with their fellow brothers and sisters, not to hurt or hurt their siblings, not hopefully to disbelieve their siblings, nor to frighten or eliminate their own siblings' blood. These actions can trigger acts of terrorism, such as the threat of bombing. In Islam's teachings, it is forbidden even to criticize a Muslim, let alone kill him, or damage things that are not appropriate 
Khazanah Sosial, Vol. 2 No. 3: 179-189

The Enforcement of Counter-Radicalism through Educational Values (Analytical analysis of the Book of I'tiqād by Al-Bukhārī)

Hanif Muhammad Kamil, Hudzaifah Achmad Qotadah, Iqbal Syafri

\section{Being peaceful with followers of other religions}

In the book I'tiqād al-Bukhārī, Imam al-Bukhārī emphasizes several verses of Al-Qur'an about the importance of coexistence between religious people both with Żimmi kafir, Kafir Mu'ahad and Kafir Musta'man as long as they do not antagonize you or attack you. As Allah says:

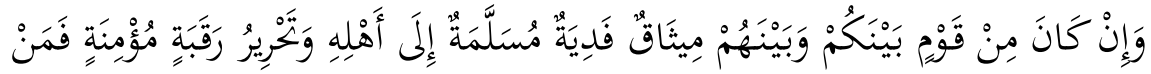

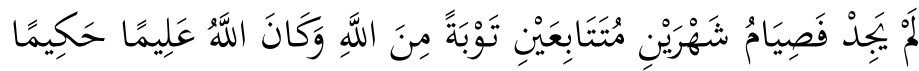

Meaning: "And if the victim is from a people bound with you in a treaty, then blood-money must be paid to the family along with freeing a believing slave. Those who are unable, let them fast two consecutive months-as a means of repentance to Allah. And Allah is All-Knowing, All-Wise." (QS. An-Nisā’: 92)."

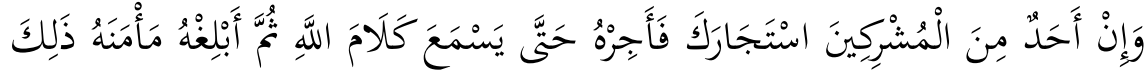

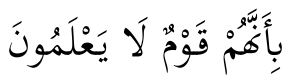

Meaning: "And if anyone from the polytheists asks for your protection 'O Prophet', grant it to them so they may hear the Word of Allah, then escort them to a place of safety, for they are a people who have no knowledge."(QS at-Taubah: 6)"

Rasūlullāh Șallallāhu 'alaihi wa Sallam said:

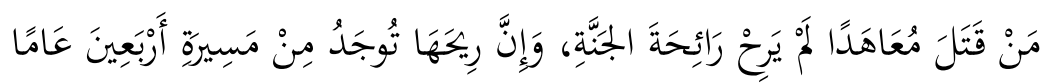

Meaning: "Whoever killed a person having a treaty with the Muslims, shall not smell the smell of Paradise though its smell is perceived from a distance of forty years (Al-Bukhārī, 2012a)"

Therefore, we can understand that fighting, in the sense of eliminating the life or soul of followers of other religions (kafir Żimmi, kafir Mu'ahad or kafir Musta'man), is an act that has violated both His words and the words of His prophet. Islam's essence is the religious teaching of rahmatan lilalamin which emphasizes the preservation of dharuriyat al khams, one of which is guarding the soul.

Based on the four educational values that the author has described above, it can be relevant to Islamic education in Indonesia. They are: First, it is not allowed to label someone as an infidel quickly; Second, one should not criticize other Muslims; Third, the obligation to hold on to what the Prophet Muhammad SAW and his companions had taught; Fourth, it should not take away leadership from its owner; Fifth, they should not scare their siblings, and they should not point their weapons at others; Sixth, A suggestion to pray for kindness to the leader.

\section{CONCLUSION}

Radicalism can emerge from anywhere regardless of the background of the perpetrators. Islam is a religion full of peace that emphasizes its people to be friendly in society. For Muslims who act radically, they do not understand the essence of Islamic teachings. Imam al-Bukhāri is an ulama who has a concept of counter-radical values in his book, including previous ulama agreement. Indonesia is a country inhabited by the majority of Muslims in the world. We need education on understanding Islam in peace, namely by deepening the knowledge of faith per the understanding of the Prophet's 


\section{Khazanah Sosial, Vol. 2 No. 3: 179-189}

The Enforcement of Counter-Radicalism through Educational Values (Analytical analysis of the Book of I'tiqād by Al-Bukhārī)

Hanif Muhammad Kamil, Hudzaifah Achmad Qotadah, Iqbal Syafri

companions. By understanding the teachings of Islam correctly, Muslims can control their emotions not to become radicalized. These counter-radical values are 1) Being peaceful with the general public. (2) Being peaceful with the government. (3) Being peaceful with fellow Muslims. (4) Being peaceful with followers of other religions. The four values of counter-radicalism are very much in line with the contents of the book I'tiqād al-Bukhārī which is the result of Imam al-Bukhārī's thought.

\section{REFERENCES}

Adz-Dzahabi, S. M. bin A. bin 'Uṡmān. (2008). Ringkasan Siyar A'lam an-Nubala, penerjemah: Fathurrahman \& Abdul Somad (Fathurrahman \& S. Abdul (eds.)). Pustaka Azzam.

Al-Asqalani, A.-H. I. H. (2001). Fath Al-Bari bi Syarh Shahih Al-Bukhari (A. Q. S. Al-Hamd (ed.)). Riyadh.

Al-Bukhārī, M. bin I. (2012a). I'tiqād Abī 'Abdillāh Muhammad bin Ismā'îl al-Bukhārī fì Jamā'ah min as-Salaf allażīna Rawā 'anhum (M. Z. bin 'Umar At-Tuklah (ed.)). Wizarah al-Awqaf alKuwaitiyah.

Al-Bukhārī, M. bin I. (2012b). Shahih al-Bukhārī. Dar Ibn Kathir.

Al-Harrani, T. A. 'Abbās A. bin 'Abdul H. bin T. (2004). Majmū Majmū'al-Fatāwā ( al-M. al-A. al-S. W. al-S. al-I. Abdurrahman Muhammad bin Qasim (ed.)). wa al-Auqaf wa al-Da'wah wa alIrsyad.

Al-Lālikā'ì, H. A. ibn al-H. ibn M. al-T. (1995). Syarh Ushūl I'tiqād Ahl al-Sunnah wa al-Jamā'ah min al-Kitāb wa al-Sunnah wa Ijmā' al-Shahābah wa al-Tābi'în min Ba'dihim (A. ibn S. ibn H. AlGhāmid (ed.)). Dār al-Thayyibah.

Al-Naysabūrī, A. al-Ḥusayn M. I. al-Hajjāj I. al-Q. (2003). Șaḥịh Muslim. Dar al-Fikr.

Al-Utsaimin, M. bin S. (2008). Musthalah al-Hadis, penerjemah: Ahmad S. Marzuqi. Media Hidayah.

Albani, M. N. Al. (1980). Dzilal Al-Jannah fi Takhriji As-Sunnah, al-Maktab al-Islami: Jami'u al-huquq al-mahfudzah.

Alia, S., Resma, N., Nurali, R., \& Hamara, H. (2020). Budaya Lembaga Pendidikan sebagai Pilar Utama Melawan Degradasi Moral. Khazanah Pendidikan Islam, 2(2), 84-89.

An-Nawawi, A. Z. M. (1930). Al Minhaj Syarh Shahih Muslim bin Hajjaj. al -Masriyah bi al- Azhar.

As-Suyuti, J. (1996). Ad-Dibaj ala Shahih Muslim bin al-Hajjaj (A. I. al-H. Al-Atsari (ed.)). Dar ibn 'Affan.

Az-Zahrani, M. bin M. (2011). Kitab-kitab Rujukan Hadits: Lengkap dengan Biografi Ulama Hadits \& Sejarah Pembukuannya (R. Muhammad \& Dkk (eds.)). Darul Haq.

Bahroni, B. (2009). Pendidikan Islam sebagai Solusi Alternatif untuk Mengatasi Kemerosotan Moralitas Anak Bangsa. INSANIA: Jurnal Pemikiran Alternatif Kependidikan, 14(2), 269-288.

BNPT. (2016). Strategi Menghadapi Paham Radikalisme Terorisme-ISIS. In Jakarta: Belmawa. Belmawa.

Budiyanto, M. (2013). Pengantar Ilmu Pendidikan. Fakultas Ilmu Tarbiyah dan Keguruan UIN Sunan Kalijaga.

Hidayat, I. (2020). Kompetensi Guru dalam Pembelajaran PAI berbasis Higher Order Thinking Skills (HOTS) di Sekolah Menengah Pertama. Khazanah Pendidikan Islam, 2(2), 52-67.

Hikam, M. A. S. (2016). Deradikalisasi: peran masyarakat sipil Indonesia membendung radikalisme. Penerbit Buku Kompas.

Jauzi, A. F. A. I. (2006). Hafalan Buyar Tanda Tak Pintar: Ternyata Kekuatan Belajar Adalah Menghafal (Solo (ed.); Irwan, Rai). Kuttab Publishing.

Kusmanto, T. Y., Fauzi, M., \& Jamil, M. M. (2015). Dialektika radikalisme dan anti radikalisme di pesantren. Walisongo: Jurnal Penelitian Sosial Keagamaan, 23(1), 27-50.

Muchith, M. S. (2016). Radikalisme dalam dunia pendidikan. Addin, 10(1), 163-180.

Nazir, M. (2014). Metode Penelitian Cet. 9. Penerbit Ghalia Indonesia. Bogor. 


\section{Khazanah Sosial, Vol. 2 No. 3: 179-189}

The Enforcement of Counter-Radicalism through Educational Values (Analytical analysis of the Book of I'tiqād by Al-Bukhārī)

Hanif Muhammad Kamil, Hudzaifah Achmad Qotadah, Iqbal Syafri

Rahmawati, U. A. (2014). Deradikalisasi Pemahaman Agama dalam Pemikiran Yusuf Qardhawi Ditinjau dari Perspektif Pendidikan Agama Islam [UIN Sunan Kalijaga Yogyakarta.]. http://digilib.uin-suka.ac.id/15104/.

Ratna, N. K. (2019). Metodologi penelitian kajian budaya dan ilmu sosial humaniora pada umumnya. Pustaka Pelajar.

Rohmatika, M. (2016). Efektivitas Peran Guru PAI di SMP Negeri 9 Yogyakarta dalam Upaya Preventif Menangkal Propaganda Radikalisme Islam pada Peserta Didik [UIN Sunan Kalijaga Yogyakarta.]. http://digilib.uin-suka.ac.id/20218/.

Rosanita, D. (2016). Persepsi Guru Pendidikan Agama Islam tentang Radikalisme Agama Studi Multisitus di SMA Negeri 1, SMK Negeri 1, dan MA Negeri 1 Kota Mojokerto. UIN Maulana Malik Ibrahim Malang.

Sajidiman, D. (2012). Administrasi \& Supervisi Pendidikan. STAI Persatuan Islam Cianjur.

Syamsuddin, D. (2016). Deradikalisasi Memunculkan Ekstremisme Baru. Suaramuhammadiyah. https://www.suaramuhammadiyah.id/2016/03/20/deradikalisme-munculkanekstrimisme-baru/

Syamsuddin, Z. A., \& Abidin, Z. (2015). Membedah Akar Fitnah Wahhabi: Buku Putih Dakwah Salafiyah. Jakarta: Pustaka Imam Bonjol.

Tahir, S. (2016). Ensiklopedi Pencegahan Terorisme. BNPT.

Wahyudi, A. (2009). Mengenal Imam Bukhari.

Zed, M. (2004). Metode penelitian kepustakaan. Yayasan Obor Indonesia. 